\title{
THE DIAGNOSIS AND RECOMMENDATION INTEGRATED SYSTEM (DRIS) - FIRST APROACH FOR THE ESTABLISHMENT OF NORMS FOR VINEYARDS IN PORTUGAL
}

\section{O SISTEMA INTEGRADO DE DIAGNÓSTICO E RECOMENDAÇÃO (DRIS) - ESTUDO DO ESTABELECIMENTO DAS NORMAS PARA A CULTURA DA VINHA EM PORTUGAL}

\author{
Anabela Carneiro ${ }^{1,4}$, Óscar Pereira ${ }^{2}$, Mário Cunha ${ }^{1,3}$, Jorge Queiroz ${ }^{1,4}$ \\ ${ }^{1}$ Faculdade de Ciências da Universidade do Porto, Departamento de Geociências, Ambiente e Ordenamento do Território, Rua Padre Armando \\ Quintas, 4485-661 Vairão, Portugal. \\ ${ }^{2}$ Direção Regional de Agricultura do Norte, Entre Douro e Minho, Quinta de Sergude - Sendim, 4610 - 764 Felgueiras, Portugal. \\ ${ }^{3}$ Centro de Investigação em Ciências Geoespaciais, Universidade do Porto. \\ ${ }^{4}$ Laboratório Associado para a Química Verde - Tecnologias e Processos Limpos (REQUIMTE), Universidade do Porto.
}

*corresponding author: Tel: +351 220402 489, Fax: +351 220402 490, e-mail: acarneiro@fc.up.pt

(Received 24.05.2015. Accepted 04.11.2015)

\section{SUMMARY}

The Diagnosis and Recommendation Integrated System (DRIS) is an alternative tool for the evaluation of nutritional status and fertilizer recommendation of several crops. However, as this methodology implies the establishment of norms or standards, without which one cannot infer about the nutritional status of a crop, in Portugal this tool has little application. The aim of this study was to establish preliminary DRIS norms for vineyards in Portugal. From 2007 to 2009, petiole samples were collected on a set of 199 selected plots. The DRIS norms were established according to the proposed by Beaufils (1973), based on the results of the laboratory procedures. The results suggest the need for further studies in order to validate the DRIS norms presented. In the future it will be important to increase the number of observations for the establishment of DRIS norms, as well as to determine the relevance of establishing specific nutritional standard according the edaphic, climatic and varietal variability of Portuguese wine regions.

\section{RESUMO}

O Sistema Integrado de Diagnóstico e de Recomendação, em língua inglesa Diagnosis and Recommendation Integrated System (DRIS) constitui uma ferramenta alternativa para a avaliação do estado nutricional e a fundamentação da recomendação de fertilização de diversas culturas. Todavia, em Portugal este é um recurso ainda pouco divulgado uma vez que tal metodologia implica o estabelecimento de valores de referência ou normas, sem os quais não se poderá inferir sobre o estado nutricional de uma dada cultura. Neste trabalho, pretendeu-se estabelecer normas DRIS para a cultura da vinha em Portugal Continental. Para tal, entre 2007 e 2009, selecionou-se um conjunto de parcelas, nas quais foram recolhidas 199 amostras de pecíolos. As normas DRIS foram calculadas de acordo com a metodologia proposta por Beaufils (1973), a partir dos resultados da análise laboratorial. Os resultados obtidos sugerem a necessidade de estudos posteriores, com vista à validação das normas DRIS apresentadas. Futuramente será importante aumentar o número de parcelas consideradas para o estabelecimento das normas DRIS, assim como averiguar a pertinência do estabelecimento de padrões nutricionais mais específicos, de acordo com a variabilidade edafoclimática e varietal das regiões vitivinícolas portuguesas.

Key words: Portugal, Vineyards, Nutrition, DRIS, Norms.

Palavras-chave: Portugal, Vinha, Nutrição, DRIS, Normas.

\section{INTRODUCTION}

Usually, fertilizer recommendations in agriculture are based on soil and plant analyzes (Coleman et al.,
2003; Pacheco et al., 2010; McCray et al., 2013). However, since the procedure based on soil analysis has some constraints as the soil samples may not be representative of the portion of soil effectively

This is an Open Access article distributed under the terms of the Creative Commons Attribution License (http://creativecommons.org/licenses/by/4.0), which permits unrestricted use, distribution, and reproduction in any medium, provided the original work is properly cited. 
explored by plants, the identification of nutrients that are really available to plants present some doubts (Meyer, 1981; Coleman et al., 2003; Pacheco et al., 2010; Horneck et al., 2011).

As a result, plant analysis is a well-accepted tool for diagnosing the nutritional requirements of agricultural and forest crops, since it provides a direct measurement of plant nutritional status (Coleman et al., 2003; Harger et al., 2003). Among all plant tissues, the leaves have the greater potential for diagnosis due to their important role on the main physiological processes of the plants, which makes the leaf analysis the most widely used resource (Malavolta et al., 1997; Coleman et al., 2003). This kind of diagnosis can suit as a complement to soil analysis, allowing greater efficiency in fertilizer applications, including the economic ones (Chapman and Brown, 1950; Malavolta et al., 1997; McCray et al., 2013). The interpretation of leaf analysis uses essentially reference values for specific levels of productivity and quality (such as the Critical Concentrations and the Sufficiency Nutrient Range Limits) (Pacheco et al., 2010). These comparisons based on the standard values are a basic methodology which considers each nutrient independently and this way difficult the application of the concept of nutritional balance, since it can only identify a nutrient at each time (Jones, 1981; Beverly, 1991). Thus, the use of such methods does not allow the rank of nutrient limitations (Meyer, 1981; Maeda et al., 2004). On the other hand, they do not consider different nutritional mechanisms of plants neither the interactions issue between nutrients (Schaller et al., 2002).

Furthermore, the standardization of the sampling period required by the above referred methods is based on the principle that higher nutrient requirements are met at the flowering stage which, in case of annual crops, prevents its results from being used on the benefit of the crop from which the sample was taken (Meyer, 1981; Harger et al., 2003; Nachtigall, 2004; Srivastava and Singh, 2008). The evolution of tissue maturation, and therefore the instability of nutritional concentrations, is another difficulty in the interpretation and the establishment of these standards as well as the quantification of its impact on production (Sumner, 1979; Nachtigall, 2004; Srivastava and Singh, 2008). Finally as these methods do not consider environmental factors or other nutritional conditions, it is assumed that the reference values listed are not unique or universally applicable, which justifies the existence of a large number of critical values referred in the literature for the same crop (Melsted et al., 1969; Srivastava and Singh, 2008).
The Diagnosis and Recommendation Integrated System (DRIS) is an alternative tool for nutrient interpretation that has been implemented in different cropping systems in several countries (Ruíz-Bello and Cajuste, 2002; Harger et al., 2003; Srivastava and Singh, 2008). Introduced by Beaufils (1973), this methodology is based on the calculation of an index for each nutrient, considering its relationship with others (Mourão-Filho, 2005; McCray et al., 2013). To this purpose, it uses a large number of nutrient concentrations and yields observations from a specific crop to obtain estimates of the average, standard deviations, variances and coefficients of variation, which constitute the comparison standards (Beaufils, 1973; Elwali and Gascho, 1983). One of the most widespread methods for establishing the DRIS norms is the criterion of greater variance ratio among populations of low and high productivity (Beaufils, 1973), tested for each nutritional ratio in forward and reverse order - " F value" (Letzsch and Sumner, 1984; Letzsch, 1985; Walworth and Sumner, 1987; Maeda et al., 2004). Years later, Nick (1998), proposed, alternatively, the criterion of "r-value". According this author, it should be chosen the nutrient ratio that results in the highest absolute value of the correlation coefficient (r) among the plant response variable (productivity) and the ratio between the pairs of nutrients both in the reverse and direct order. Those values, resulting from the application of one of the above two methods, will compose the DRIS reference parameters established from a nutritionally balanced and high productivity subpopulation, also known as standards or norms (Beaufils, 1973; Elwali and Gascho, 1983; Bailey et al., 1997; Ruíz-Bello and Cajuste, 2002; McCray et al., 2013). By comparing the ratios of the nutrients in a tissue sample with the standard, using the calculation functions which are then used to set rates, it is possible to determine which nutrients are limiting crop yield (Beaufils, 1973; Elwali and Gascho, 1983; Bailey et al., 1997; Ruíz-Bello and Cajuste, 2002; McCray et al., 2013). The DRIS method either calculates the nutritional balance index (NBI), which allows inferring about the nutritional balance of the plant (Elwali and Gascho, 1983; Tomé, 2001; Mourão-Filho, 2005).

According Beaufils and Sumner (1975), the main advantage of the DRIS methodology is its applicability to a specific crop in any place and at any stage of development. Based on nutrient relative concentrations in plant tissues (rather than absolute), it is less sensitive to plant development stage and respective concentration or dilution effect on nutrient content, resulting from biomass production (Bailey et al., 1997; Tomé, 2001). Hence if the leaf samples are taken over a longer period of time and the identification of nutrient limitations is done at an 
earlier stage of development of the crop, it is possible to recognize or even fix the problem in the same year (Walworth and Sumner, 1987; Harger et al., 2003). Furthermore, according to Beverly (1991), Ruiz-Bello and Cajuste (2002), or Raj and Rao (2006), the DRIS points out other limiting nutrients not detected by conventional methods whose application result in the increase of the crop production. Nonetheless, the development and use of DRIS should be considered as a dynamic process that needs a database and the reference values constantly extended, for their greater efficiency in the nutritional diagnosis (Maeda et al., 2004). Thus, one of the difficulties encountered when using DRIS is the obtainment of a representative number of high-yielding populations (Elwali and Gascho, 1984; Letzsch and Sumner, 1984). Also the extensive and advanced number of calculations, given the complexity of the method, discouraged its use (Jones, 1981; Mourão-Filho, 2004). On the other hand, if the interdependence between nutrients proposed by DRIS method allows their classification and ranking, it also proves to be a huge disadvantage since it can be disclosed into false diagnoses due to the distortions caused by uncontrolled factors such as foliar contamination, antagonistic effects between nutrients or even by calculation issues inherent to the methodology (Elwali and Gascho, 1983, 1984; Mourão-Filho, 2004). Furthermore, the influence of the leaf age and the type of tissue sampled has been considered in the course of several studies. Whether works developed by Beaufils and Sumner (1976), with sugarcane, Sumner (1977), with corn and Harger et al. (2003), with soybean concluded that the DRIS methodology is independent of the age of the plant, other authors claim that DRIS is affected by the age and type of tissue sampled (Meyer, 1981; Beverly et al., 1984; Cerdá et al., 1995). In addition, the universality of DRIS norms does not meet consensus among the authors who have studied this methodology. Theoretically, standard values should be applied to the crop in question, irrespective of place where it is grown (Beverly, 1991). Therefore, the data collected for the establishment of standards should be as general as possible, in order to enframe a large number of individuals, randomly selected in a wide range of geographical and environmental conditions, so that it can be universally applicable to the same crop (Sumner and Beaufils, 1975; Sumner, 1979). However, in fact, Beverly (1991), and Tomé (2001), consider that the use of regional norms, derived from soil and local climate conditions, adapted to varieties and rootstocks are the most appropriate, since DRIS is also influenced by the same factors that interfere with other methods of nutritional status analysis. Thus, it is considered that, despite the additional benefits, the nutritional diagnosis based on DRIS should be considered in parallel with the conventional methodology. Information such as soil analysis, cultural practices or even the experience in crop management can provide very important complementary data in the assessment of nutritional status of a sample, allowing the most suitable fertilization procedure (Beaufils and Sumner, 1976; Beverly et al., 1984; Walworth and Sumner, 1987; McCray et al., 2013).

Regarding Vitis vinifera spp., there are few studies published concerning this methodology application. Among the studies of Chelvan et al. (1984), Schaller et al. (2002), Sharma et al. (2005), or Martín et al. (2013), which were performed in different vineyards, it was detected the instability of the indices according to each phenological stage and tissue analyzed. Given those results, Schaller et al. (2002), suggest that, as a perennial crop, the nutrient storage capacity of a vine in organs such as arms, trunk and roots is responsible for changing the expected response to a regular fertilizer application. In addition to the difficulty on the obtainment of DRIS indices, most of the published works focuses only on the production criteria (Martín et al., 2013). Nonetheless, such a method would be pointless in a perspective of a modern viticulture focused on the achievement of high quality must, since in grapes high efficiency is not so important as quality (Schaller et al., 2002; Martín et al., 2013). Therefore, according to these authors, it is mandatory the development of a mixed criterion for the definition of the reference population that matches the average production and preserves the quality of the must obtained.

In our country, the most widespread method of nutritional analysis and fertilizer recommendations used for vineyards is still the Sufficiency Nutrient Range Limits (Pacheco and Vieira, 2004). The study of alternative methods has been neglected hence there is little information available. The first steps on the study and implementation of DRIS enclose a comparison of some methods for diagnosis of nutritional status applied to pear tree, cultivar 'Rocha' (Alves, 1997), the application of the DRIS method for the kiwi orchards (Veloso, 1995) or the suitability of the methodology in vines (Carneiro et al., 2010).

Given the role of the nutritional status of crops on the quantity and quality of production, and encouraged by the lack of technical and scientific information about DRIS, the purpose of this study was to establish the DRIS norms for vineyards in Portugal. 


\section{MATERIAL AND METHODS}

Between 2006 and 2009, in partnership with farmer associations and companies, 199 vineyard plots distributed across North (43\%), Center (37\%) and South $(20 \%)$ of Portugal were selected for this study following a similar distribution of the vineyard area in Portugal. These vineyards, randomly selected among a larger universe and chosen concerning the varieties, rootstocks, training systems, agronomic practices, soil and climate conditions and types of wine produced, were further divided into two different groups according to the national level of average production ( 5 ton/ha), after data published by the "Instituto Nacional de Estatística" (INE, 2012) and defined with the cooperating institutions,

- 99 plots of High Yield group: high or very high yields ( $\geq 5$ ton/ha), considered reference plots for following the principles of good viticulture practices, and;

- 100 plots of Low Yield group: characterized by low or very low yield ( $<5$ ton/ha).

After identification and characterization of the vineyard plots, soil, leaf and fruit samples were collected according to the rules adopted in Integrated Production (Cavaco et al., 2005), which were latter analyzed in the laboratory. Regarding leaf analysis, the sampling period was the flowering stage. The analytical parameters determined in the petioles of the leaves, sampled from a shoot in the middle third of the vine cordon and opposite to the basal cluster, were: N - Kjeldahl method (Kjeldahl, 1883); P digestion with nitric acid and quantification by colorimetry (Murphy and Riley, 1962; Watanabe and Olsen, 1965); K, Ca, Mg, Cu, Zn, Mn and Fe microwave digestion based on the method described by Kingston and Jassie (1986, 1988), and modified by Sah and Miller (1992), using HNO3 and 30\% H2O2 and an atomic absorption spectroscopy flame assay; B - digestion with sulfuric acid and colorimetric determination (Ellis et al., 1949). Other performed analyzes, will not be considered in this work as they provided only an auxiliary characterization of the plots. Based on the analytical data, the preliminary DRIS norms were established for the Portuguese viticulture. In fact, despite the both methodologies reported in the literature, it was only considered the criterion of $F$ value. The latter method $-r$ value, proposed by Nick (1998), was not contemplated since not all the institutions provided information about the yield. Likewise Beaufils (1973), or Elwali and Gascho (1984), the DRIS reference parameters for each nutrient consisted in those forms of expressions (each nutrient was expressed as a numerator or a denominator of ratios with each of the other nine nutrients) which gave the highest significant variance ratios between the two sub-populations.

\section{RESULTS AND DISCUSSION}

Although preliminary, the DRIS norms for Portuguese vineyards were established based on results obtained in this work which are discriminated in Table I.

The results show that the nutritional relationships as also the DRIS norms obtained are not the same as those published and reported in literature for Vitis vinifera spp. by Chelvan et al. (1984), Schaller et al. (2002), Sharma et al. (2005) or Martin et al. (2013), which would be expected, given not only the variability of the values found in the literature, but also the fact that the vine is a perennial crop. Therefore, issues such as nutrient storage in different organs, the existence of nutritional disorders that can affect the plants cumulatively over the years, the impact of management decisions, water relations, environmental conditions or even the occurrence of pest and diseases, have their influence on the vineyard nutrition, which can lead to a change in the expected response for a given fertilizers application as proven by Schaller et al. (2002), Terra et al. (2002), and Martín et al. (2013). On the other hand, we question the universality of DRIS norms whereas some studies such as those performed by Beaufils and Sumner (1975), or by Sumner (1979), argue that the DRIS norms should be universally applied. In fact this standard values are susceptible to vary depending on the conditions that the crops are subject to (soil, climate, geographical location, varieties and rootstocks, etc.), according to the studies of numerous authors like Beverly (1991), Tomé (2001), or Maeda et al. (2004). Consequently, although the Portuguese average yield is 5 tons per hectare, regarding the variability in our country, the factors selected by the producer such as varieties, rootstocks, training systems or vineyard management, among others or the variables imposed by the region or the plot itself, such as edaphic or climatic conditions, explain the huge disparity of yield values per hectare obtained in this work. This situation lead us to consider that DRIS norms would be much more reliable if the reference populations were established region by region, fixing the largest possible number of variables. As also mentioned in the bibliography, factors such as the size of the standard population or the age of the sampled tissue may also have some influence on the results. However, this work was developed using a database set in order to cover the national variability and it was decided to perform the sampling at the flowering stage, the same criteria adopted by the 
Sufficiency Nutrient Range Limits, widely reported in our country. Yet, the coefficients of variation found are very high (Table I), indicating the large variability of the obtained results (Veloso, 1995; Morales, 2004). This dispersion magnitude is higher than desired, demonstrating the importance of gathering a larger number of data, according to different plant, soil and climate conditions (Veloso, 1995; Morales, 2004). One last feature related to the establishment of DRIS nutritional standards and reported by Martin et al. (2013), is the difficulty in attaining DRIS indices for vineyards bearing in mind the quality criteria, which is equally or even more important than the quantity of grapes harvested. That will explain our decision to evaluate quantitatively the samples considered in this work.

Table I

DRIS norms - mean and coefficient of variation (CV) (\%)

Normas DRIS - média e coeficiente de variação (CV) (\%)

\begin{tabular}{|c|c|c|c|c|c|}
\hline Ratio & Mean & CV (\%) & Ratio & Mean & CV (\%) \\
\hline $\mathrm{N} / \mathrm{P}$ & 2.670 & 182.51 & $\mathrm{~K} / \mathrm{B}$ & 0.603 & 66.17 \\
\hline $\mathrm{N} / \mathrm{K}$ & 0.540 & 70.37 & $\mathrm{Ca} / \mathrm{Mg}$ & 2.483 & 60.65 \\
\hline N/Ca & 0.594 & 50.34 & $\mathrm{Ca} / \mathrm{Cu}$ & 1.830 & 54.10 \\
\hline N/Mg & 1.349 & 64.79 & $\mathrm{Ca} / \mathrm{Fe}$ & 0.781 & 69.53 \\
\hline $\mathrm{Cu} / \mathrm{N}$ & 0.977 & 59.26 & $\mathrm{Ca} / \mathrm{Mn}$ & 0.119 & 113.45 \\
\hline $\mathrm{N} / \mathrm{Fe}$ & 0.440 & 75.68 & $\mathrm{Ca} / \mathrm{Zn}$ & 0.423 & 53.19 \\
\hline $\mathrm{Mn} / \mathrm{N}$ & 0.060 & 123.33 & $\mathrm{Ca} / \mathrm{B}$ & 0.501 & 56.69 \\
\hline N/Zn & 0.217 & 47.00 & $\mathrm{Mg} / \mathrm{Cu}$ & 0.873 & 58.76 \\
\hline N/B & 0.278 & 72.30 & $\mathrm{Mg} / \mathrm{Fe}$ & 0.372 & 68.01 \\
\hline $\mathrm{K} / \mathrm{P}$ & 0.281 & 58.72 & $\mathrm{Mg} / \mathrm{Mn}$ & 0.053 & 109.43 \\
\hline $\mathrm{Ca} / \mathrm{P}$ & 0.297 & 48.15 & $\mathrm{Mg} / \mathrm{Zn}$ & 0.193 & 51.30 \\
\hline $\mathrm{Mg} / \mathrm{P}$ & 0.678 & 60.03 & $\mathrm{Mg} / \mathrm{B}$ & 0.252 & 103.97 \\
\hline $\mathrm{P} / \mathrm{Cu}$ & 0.507 & 57.00 & $\mathrm{Cu} / \mathrm{Fe}$ & 0.546 & 103.48 \\
\hline $\mathrm{P} / \mathrm{Fe}$ & 0.235 & 89.79 & $\mathrm{Cu} / \mathrm{Mn}$ & 0.079 & 146.84 \\
\hline $\mathrm{P} / \mathrm{Mn}$ & 0.030 & 96.67 & $\mathrm{Cu} / \mathrm{Zn}$ & 0.283 & 96.82 \\
\hline $\mathrm{Zn} / \mathrm{P}$ & 0.115 & 56.52 & $\mathrm{Cu} / \mathrm{B}$ & 0.363 & 106.34 \\
\hline $\mathrm{P} / \mathrm{B}$ & 0.132 & 48.48 & $\mathrm{Mn} / \mathrm{Fe}$ & 0.203 & 169.95 \\
\hline $\mathrm{K} / \mathrm{Ca}$ & 1.322 & 51.51 & $\mathrm{Zn} / \mathrm{Fe}$ & 0.815 & 103.68 \\
\hline $\mathrm{K} / \mathrm{Mg}$ & 3.209 & 85.01 & $\mathrm{~B} / \mathrm{Fe}$ & 0.887 & 82.30 \\
\hline $\mathrm{K} / \mathrm{Cu}$ & 2.134 & 56.42 & $\mathrm{Zn} / \mathrm{Mn}$ & 6.190 & 76.28 \\
\hline $\mathrm{K} / \mathrm{Fe}$ & 0.977 & 81.37 & $\mathrm{~B} / \mathrm{Mn}$ & 7.935 & 87.30 \\
\hline $\mathrm{K} / \mathrm{Mn}$ & 0.135 & 120.00 & $\mathrm{~B} / \mathrm{Zn}$ & 1.449 & 79.50 \\
\hline $\mathrm{K} / \mathrm{Zn}$ & 0.485 & 50.93 & & & \\
\hline
\end{tabular}

\section{CONCLUSIONS}

This is the first approach for the establishment of DRIS norms for vineyards in Portugal. Nonetheless, the few DRIS norms published for this crop are inconsistent and do not often contemplate the quality factor, which is of great importance. However, considering the results obtained and the opinion of some authors who defend the adequacy of these reference relations to regional constraints, these preliminary DRIS norms should be carried out with some reservations. As mentioned by some authors and supported by the results achieved, before widespread and validation of the DRIS as a nutritional tool for fertilizer recommendations in 
vineyards, it would be valuable to improve plot selection, namely by increasing the number of observations gathering yield information and quality parameters. Other factors, such as the (in)dependence of the sampling time or the type of tissue harvested, as well as quantifying the environmental potential and economic benefits inherent to the method, should be considered. Furthermore, it would be important the establishment of nutritional standards based on representative data of the edaphic, climatic and varietal variability of Portuguese wine regions.

\section{ACKNOWLEDGMENTS}

AANT - Associação dos Agricultores do Nordeste Transmontano; AAPIM - Associação de Agricultores

\section{REFERENCES}

Alves M., 1997. Estudo comparativo da aplicação de alguns métodos de diagnóstico do estado de nutrição das plantas cultivadas. Caso da pereira (Pyrus communis L.) cultivar Rocha. 206 p. Tese de Doutoramento, Instituto Superior de Agronomia da Universidade Técnica de Lisboa.

Bailey J.S., Beattie J.A.M., Kilpatrick D.J., 1997. The diagnosis and recommendation integrated system (DRIS) for diagnosing the nutrient status of grassland swards: I. Model establishment. Plant and Soil, 197, 127-135.

Beaufils E.R., 1973. Diagnosis and Recommendation Integrated System (DRIS). A general scheme of experimentation and calibration based on principles developed from research in plant nutrition. 132 p. University of Natal, Pietermaritzburg, South Africa.

Beaufils E., Sumner M., 1975. Diagnosis of the NPK requirements of sugarcane irrespecitive of plant age and season using Beaufils' System (DRIS) - Preliminary observations. Proceedings of the South African Sugar Technologists Association, p. 137-141.

Beaufils E., Sumner M., 1976. Application of DRIS approach for calibrating soil and plant factors in their effects on yield of sugarcane. Proceedings of the South African Sugar Technologists' Association, p. 118-124.

Beverly R., 1991. A practical Guide to the Diagnosis and Recommendation Integrated System (DRIS), 87 p. Micro-Macro Publishing, Georgia, Athens.

Beverly R., Stark J., Ojala J., Embleton T., 1984. Nutrient diagnosis of 'Valencia' oranges by DRIS. J. Am. Soc. Hortic. Sci., 109, 649-654.

Carneiro A., Cunha M., Pereira O., Queiroz J., 2010. Avaliação nutricional da videira pelo sistema integrado de diagnóstico e recomendação (DRIS). $8^{\circ}$ Simpósio de Vitivinicultura do Alentejo, Évora, 487-495.

Cavaco M., Calouro F., Clímaco P., 2005. Produção Integrada da cultura da vinha, 146 p. MADRP/DGPC, Oeiras.

Cerdá A., Nieves M., Martínez V., 1995. An evaluation of mineral analysis of Verna lemons by DRIS. Commun. Soil Sci. Plant Anal., 26, 1697-1707. para a Produção Integrada de Frutos de Montanha; AATM - Associação de Agricultores de Trás-osMontes; AFUVOPA - Associação dos Fruticultores, Viticultores e Olivicultores do Planalto de Ansiães; APPITAD - Associação de Produtores em Protecção Integrada de Trás-os-Montes e Alto Douro; ATEVA - Associação Técnica dos Viticultores do Alentejo; SOC. VINHOS BORGES - Sociedade dos Vinhos Borges.

Fundação para a Ciência e a Tecnologia: For funding this project, Programa IDEIA da ADI - Agência de Inovação and Bolsa de Doutoramento (SFRH/BD/37367/2007), assigned to the first author.

Chapman H.D., Brown S.M., 1950. Analysis of orange leaves for diagnosing nutrient status with reference to potassium. Hilgardia, 19, 501-540.

Chelvan R., Shikhamany S., Chadha K., 1984. Evaluation of low yielding vines of Thompson seedless for nutrient indices by DRIS analysis. Indian J. Hortic., 41, 166-170.

Coleman M.D., Chang S.X., Robison D.J., 2003. DRIS analysis identifies a common potassium imbalance in sweetgum plantations. Communications in soil science and plant analysis, 34, 1919-1941.

Ellis G.H., Zook E.G., Baudisch O., 1949. Colorimetric determination of boron using 1,1'-Dianthrimide. Anal. Chem., 21 (11), 1345-1348.

Elwali A., Gascho G., 1983. Sugarcane response to P, K, and DRIS corrective treatments on Florida histosols. Agron. J., 75, 79-83.

Elwali A., Gascho G. 1984. Soil testing, foliar analysis, and DRIS as guides for sugarcane fertilization. Agron. J., 76, 466-470.

Harger N.R., Fioretto R., Ralisch R., 2003. Avaliação nutricional da cultura da soja pelos métodos DRIS e níveis de suficiência. Semina: Ciências Agrárias, 24, 219-224.

Horneck D.A., Sullivan D.M., Owen J.S., Hart J.M., 2011. Soil test interpretation guide, 12 p. Oregon State University Extension Service (ed.), Oregon.

INE, 2012. Previsões Agrícolas 31 de julho 2012, 5p. INE (ed.), Lisboa.

Jones C., 1981. Proposed modifications of the Diagnosis and Recommendation Integrated System (DRIS) for interpreting plant analyses. Commun. Soil Sci. Plant Anal., 12, 785-794.

Kingston H.M., Jassie L.B., 1986. Microwave energy for acid decomposition at elevated temperatures and pressures using biological and botanical samples. Anal. Chem., 58, 2534-2541.

Kingston H.M., Jassie L.B., 1988. Monitoring and predicting parameters in microwave dissolution. In: Introduction to Microwave Sample Preparation. 97-148. Kingston, H.M., Jassie, L.B. (eds.), American Chemical Society, Washington, D.C.

Kjeldahl J., 1883. Neue Methode zur Bestimmung des Stickstoffs in organischen Körpern, Z. Anal. Chem., 22 (1), 366-383. 
Letzsch W., 1985. Computer program for selection of norms for use in the diagnosis and recommendation integrated system (DRIS). Commun. Soil Sci. Plant Anal., 16, 339-347.

Letzsch W., Sumner M., 1984. Effect of population size and yield level in selection of diagnosis and recommendation integrated system (DRIS) norms. Commun. Soil Sci. Plant Anal., 15, 9971006

Maeda S., Ronzelli P., Lucchesi L.A., 2004. Valores de referência do DRIS para a soja, cv. CD 202, para a região Sul do Mato Grosso do Sul. Scientia Agraria, 5, 35-42.

Malavolta E., Vitti G., Oliveira A., 1997. Avaliação do estado nutricional das plantas: princípios e aplicações, 319 p. 2.ed., Piracicaba, Potafós.

Martín I., Benito A., Romero I., Domínguez N., García-Escudero E., 2013. Preliminary diagnosis and recommendation integrated system norms for leaf nutrient diagnosis of Tempranillo grapevine in the Rioja Appellation. Commun. Soil Sci. Plant Anal., 44, 655667.

McCray J., Rice R., Ezenwa I., Lang T., Baucum L., 2013. Sugarcane Plant Nutrient Diagnosis - SS-AGR-128, 12 p. University of Florida - IFAS Extension (Ed.), Florida.

Melsted S., Motto H., Peck T., 1969. Critical plant nutrient composition values useful in interpreting plant analysis data. Agron. J., 61, 17-20.

Meyer J., 1981. An evaluation of DRIS based on leaf analysis for sugarcane in South Africa. Proceedings of the South African Sugar Technologists' Association, 55, 169-176.

Morales M., 2004. Normas DRIS preliminares para nogal pecanero - Preliminary DRIS norms for Pecan Tree. Terra Latinoamericana, 22, 445-450.

Mourão-Filho F., 2004. DRIS: Concepts and applications on nutritional diagnosis in fruit crops. Sci. Agric., 61, 550-560.

Mourão-Filho F., 2005. DRIS and Sufficient Range Approaches in nutritional diagnosis of "Valencia" sweet orange on three rootstocks. J. Plant Nutr., 28, 691-705.

Murphy J., Riley J.P., 1962. A modified single solution method for the determination of phosphate in natural waters. Anal. Chim. Acta, 27, 31-36.

Nachtigall G., 2004. Sistema Integrado de Diagnose $e$ Recomendação (DRIS) para avaliação do estado nutricional da macieira no sul do Brasil. 141 p. Tese de Doutoramento, Escola Superior de Agricultura "Luiz de Queiroz". Universidade de São Paulo.

Nick J., 1998. DRIS para cafeeiros podados, 86 p. Tese de Mestrado, Escola Superior de Agricultura "Luiz de Queiroz". Universidade de São Paulo.

Pacheco C., Jordão P., Vieira S., Santos F., Comenda J., Santos M., Roque Vale C., Prates M., 2010. Preliminary reference values for leaf-analyses of Vitis vinifera Trincadeira/99R in Portuguese Region of Borba. Acta Hortic., 868, 225-230.
Pacheco C., Vieira S., 2004. A fertilização racional da vinha. 37 p. AVAPI - Associação para a Valorização Agrícola em Produção Integrada, Alcobaça.

Raj G.B., Rao A.P, 2006. Identification of yield-limiting nutrients in mango through DRIS indices. Commun. Soil Sci. Plant Anal., 37, 1761-1774.

Ruíz-Bello A., Cajuste L.J., 2002. Controlling fertilizer applications through plant analysis. Commun. Soil Sci. Plant Anal., 33 (15/18), 2793-2802.

Sah R.N., Miller R. O., 1992. Spontaneous reaction for acid dissolution of biological tissue in closed vessels. Anal. Chem., 64, 230-233.

Schaller K., Löhnertz O., Michel H., 2002. Modified DRIS-System for leaf analysis to optimise fertilizer inputs - further developments with grapevines. Acta Hortic., 594, 369-375.

Sharma J., Shikhamany S., Singh R., Raghupathi H., 2005. Diagnosis of nutrient imbalance in Thompson seedless grape grafted on Dog Ridge rootstock by DRIS. Commun. Soil Sci. Plant Anal., 36, 2823-2838.

Srivastava A.K., Singh S., 2008. DRIS norms and their field validation in Nagpur Mandarin. J. Plant Nutr., 31, 1091-1107.

Sumner M., 1977. Effect of corn leaf sampled on N, P, K, Ca and $\mathrm{Mg}$ content and calculated DRIS indices. Commun. Soil Sci. Plant Anal., 8, 269-280.

Sumner M., 1979. Interpretation of foliar analyses for diagnostic purposes. Agron. J., 71, 341-348.

Sumner M., Beaufils E., 1975. Diagnosis of the NPK requirements of sugarcane irrespective of plant age and season using Beaufils system (DRIS) - Preliminary observations. Proceedings of the South African Sugar Technologists' Association, 49, 137-141.

Terra M., Guilherme M., dos Santos W., Paioli-Pires E., Pommer C., Botelho R., 2002. Avaliação do estado nutricional da videira 'Itália' na região de Jales, SP, usando o sistema integrado de diagnose e recomendação. Revista Brasileira de Fruticultura, 25 309-314.

Tomé Jr J., 2001. DRIS da Compo do Brasil: CliqFolha (C Programa Para Diagnóstico Nutricional das Culturas pelo DRIS, 7 p.

Veloso A., 1995. Condições de nutrição da actinídea no Noroeste de Portugal - Contributo para a aplicação do método DRIS. $110 \mathrm{p}$. Tese de Mestrado, Instituto Superior de Agronomia da Universidade Técnica de Lisboa.

Walworth J., Sumner M., 1987. The diagnosis and Recommendation Integrated System (DRIS). Adv. Soil Sci., 6, 149188.

Watanabe F.S., Olsen S. R., 1965. Test of an ascorbic acid method for determining phosphorus in water and $\mathrm{NaHCO} 3$ extracts from soil. Soil Sci. Soc. Am. Pro., 29, 677-678. 